PUBLISHED BY THE AMERICAN MUSEUM OF NATURAL HiSTORY CENTRAL PARK WEST AT 79TH STREET, NEW YORK, NY 10024 Number 3292, 15 pp., 5 figures

March 16, 2000

\title{
A Middle Devonian Trilobite Assemblage from Venezuela
}

\author{
MARIA DA GLORIA PIRES DE CARVALHO ${ }^{1}$ AND JOHN MOODY ${ }^{2}$
}

\begin{abstract}
Three new species of trilobites are described from the upper level of the Caño del Oeste Formation (Middle Devonian) of Venezuela. These taxa include a phacopinine, Viaphacops venezuelensis, n. sp., and two asteropyginines, Rhenops odremani, n. sp., and Greenops perijaensis, n. sp. The biogeographic implications of these records are discussed. Viaphacops is somewhat cosmopolitan in its distribution. The presence of Rhenops in Venezuela represents a profound range extension beyond the Rhenish-Bohemia region of the Old World Realm. The Venezuelan occurrence of Greenops represents a southerly range extension within the Eastern Americas Realm, reinforcing faunal similarities previously recognized among Devonian brachiopods and trilobites of Venezuela and North America.
\end{abstract}

\section{RESUMEN}

Se describen tres especies nuevas de trilobites provenientes del nivel más alto de la Formatión Caño del Oeste (Devónico medio) de Venezuela. Estos taxones incluyen un facopinino, Viaphacops venezuelensis, n. sp., y dos asteropigininos, Rhenops odremani, n. sp. y Greenops perijaensis, n. sp. Se discuten las implicancias biogeográficas de estos registros. Viaphacops tiene una distribución amplia. La presencia de Rhenops en Venezuela representa una extensión significativa de su distribución más allá de la región Rheno-Bohemia del Viejo Mundo. El registro de Greenops en Venezuela extiende su distribución hacia el sur dentro del Dominio del Este de las Américas, apoyando las similtudes reconocidas previamente, entre los braquiópodos y los trilobites devónicos de Venezuela y América del Norte.

${ }^{1}$ Research Associate, Division of Paleontology, American Museum of Natural History.

${ }^{2}$ Professor, Sección de Paleontología, Museo de Biología, Universidade del Zulia, Facultad de Ciencias, Apartado 526, Maracaibo 4011, Zulia, Venezuela. 


\section{INTRODUCTION}

The Devonian marine invertebrate fauna from Venezuela has been known since the beginning of the 20th century (Yeakel, 1924; Weisbord, 1926; Liddle et al., 1943), following early expeditions to collect fossils from the type locality of the Caño del Oeste Formation (Middle Devonian; Eifelian-Givetian), which extends along the Cachirí river in the Perijá Mountains. Benedetto (1979, 1984) subsequently described assemblages of pelecypods, trilobites, and brachiopods that were collected from several exposures of the Caño del Oeste Formation in the area of Caño Colorado (fig. 1). The trilobites described in the present work were also collected from this region.

The first Devonian trilobite described from Venezuela (a fragmentary specimen lacking the cephalon, deposited in the Cornell University Paleontological Laboratory) was referred to Phacops argentinus Thomas (Weisbord, 1926). Eldredge and Ormiston (1979: 148) suggested that it may belong to Viaphacops, and according to Benedetto (1979: 85) Weisbord's material was probably collected from the Caño Grande Formation, which underlies the Caño del Oeste Formation and is probably of Lower Devonian age. Additional trilobites from Caño del Oeste Formation were described by Benedetto (1979), who identified a phacopinine (Phacops sp. cf. P. rana; ibid., 96-97, pl. 4, figs. 1-7) and two asteropyginines (Greenops sp., plus gen. and sp. indet.; ibid., 97-98, pl. 4, figs. 8, 9). As discussed below, Benedetto's (1979) phacopinine apparently differs in several respects from the material described here as Viaphacops. Thus, the assemblage probably contains at least two different phacopinines, although only Viaphacops is represented in the new sample (the identity of Weisbord's original specimen is left an open question). Two asteropyginine taxa are also described here, but it is not possible to compare these with Benedetto's examples because critical characters cannot be determined from his descriptions or illustrations. Unfortunately, no direct comparison with any of his original material (which was deposited in the Ministerio de Energía y Minas collection) is possible because that material was either destroyed in a fire at Mérida or was lost during its relocation to Caracas, according to Venezuelan ministry officials.

In the present work, new species of Viaphacops, Greenops, and Rhenops are described. This material was collected by one of us (J. M.) and is housed in the Museo de Biología, Universidad de Zulia (MBLUZ), Maracaibo, Venezuela. Casts of this material are also deposited in the fossil invertebrate collection of the American Museum of Natural History.

The presence of Greenops in the Devonian of Venezuela supports the proposed biogeographic connection with the Eastern Americas Realm, and the presence of Rhenops in the Venezuelan assemblage suggests a link with the Rhenish-Bohemian subprovince of Europe and Morocco (part of the Old World Realm; Boucot, 1988). Viaphacops is more widespread and occurs in three different biogeographic realms. The biogeographic significance of these trilobites is discussed further below.

\section{LOCALITIES AND STRATIGRAPHY}

The Caño del Oeste Formation has long been considered to be of Middle Devonian age (Barret and Isaacson, 1988; Benedetto, 1979, 1984; Weisbord, 1926). This formation, first described by Liddle et al. (1943), represents the middle beds of the Rio Cachirí Group (Sutton, 1936), and consists principally of fine-grained, micaceous, quartzitic sandstones, siltstones, and shales. In the type section, the formation may be up to $1000 \mathrm{~m}$ in thickness, but in the area from which the present material was collected (a few kilometers south of the type section), it is less than $400 \mathrm{~m}$ thick. The contact with the underlying Caño Grande Formation (Early Devonian) is faulted (Liddle et al., 1943; Hea and Whitman, 1960; Benedetto, 1984). The Campo Chico Formation (Upper Devonian) appears to be transitional from a near-shore marine environment to one that is dominated by terrestrial deposits (Benedetto, 1984; Berry et al., 1993).

All of the specimens were collected from three localities along old and new parts of the Rio Socuy Road, between 1.2 and $2.5 \mathrm{~km}$ north of Hacienda El Reposo, and along the 


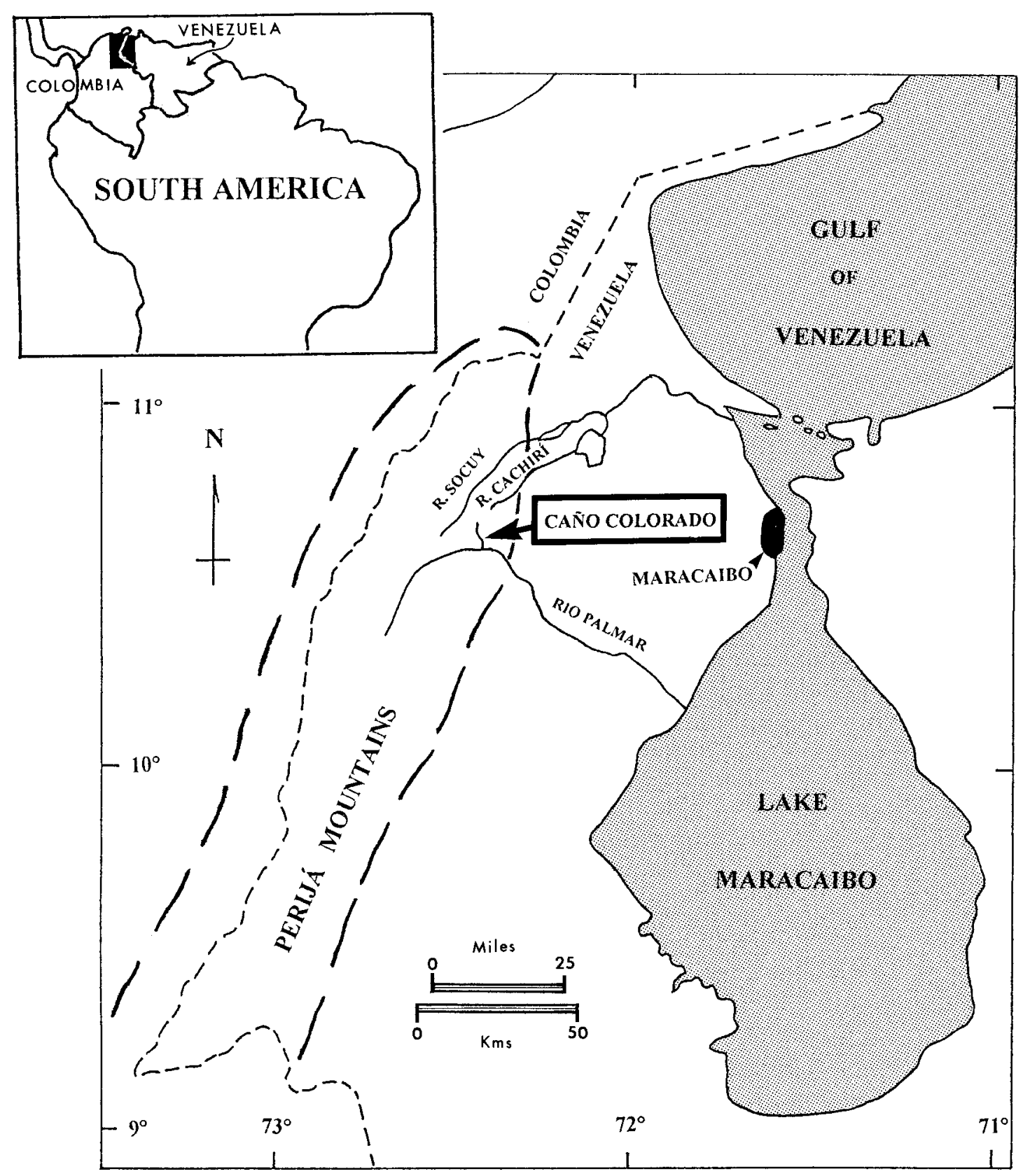

Fig. 1. Locality map of the Caño Colorado Area, Perijá Mountains, Zulia State, Venezuela, with insert map of northern South America. Approximate limit of Perijá Mountains indicated by stronger dashed line.

high, eastern flank of the upper valley formed by Caño Colorado, a northern tributary of Rio Palmar in the Perijá Mountains, Zulia, Venezuela (fig. 1). The collections from along the old road correspond to Level Co7 of Benedetto (1984), whereas the new road collecting locality, which was exposed after Benedetto made his collections, proba- 
bly represent beds of his Level Co4, and possibly slightly higher (fig. 2). Fragmentary trilobites have also been collected from additional beds of the Caño del Oeste Formation between Levels Co4 and Co7, so trilobites are probably present throughout the upper section.

Morphological terminology follows that used in the Treatise on Invertebrate Paleontology, Part O (Struve, 1959), Eldredge (1972, 1973), and Lieberman and Kloc (1997).

\section{SYSTEMATIC PALEONTOLOGY}

\author{
CLASS TRILOBITA WALCH, 1771 \\ ORDER PHACOPIDA SALTER, 1864 \\ SUBORDER PHACOPINA STRUVE, 1959 \\ SUPERFAMILY PHACOPOIDEA HAWLE AND \\ CORDA, 1847 \\ FAMILY PHACOPIDAE HAWLE AND CORDA, \\ 1847 \\ SUBFAMILY PHACOPINAE HAWLE AND CORDA, \\ 1847
}

Genus Viaphacops Maximova, 1972

TyPe SPECIES: Phacops pipa Hall and Clarke, 1888; early Middle Devonian of North America (New York State, Michigan and Southern Ontario).

Generic Diagnosis (Maximova, 1972): Preoccipital lobe entirely reduced; preoccipital furrow merged with occipital furrow to form a deep broad furrow on site of preoccipital lobe. Occipital ring usually narrow. Vincular furrow deep, with prominent inner border. Eyes of moderate size, less frequently large. Pygidium usually wide, weakly segmented. Surface of glabella with fairly large nodes.

Systematic Note: Those phacopids that were originally placed in the genus Phacops from Central Kazakhstan and the Far Eastern part of the former Soviet Union were reexamined by Maximova (1972), who erected a new genus, Paciphacops, with two subgenera, P. (Paciphacops) and P. (Viaphacops), each containing several species. Elsewhere Viaphacops has been elevated to generic rank (e.g., Ramsköld and Werdelin, 1991; Linsley, 1994) and that practice is also followed here.

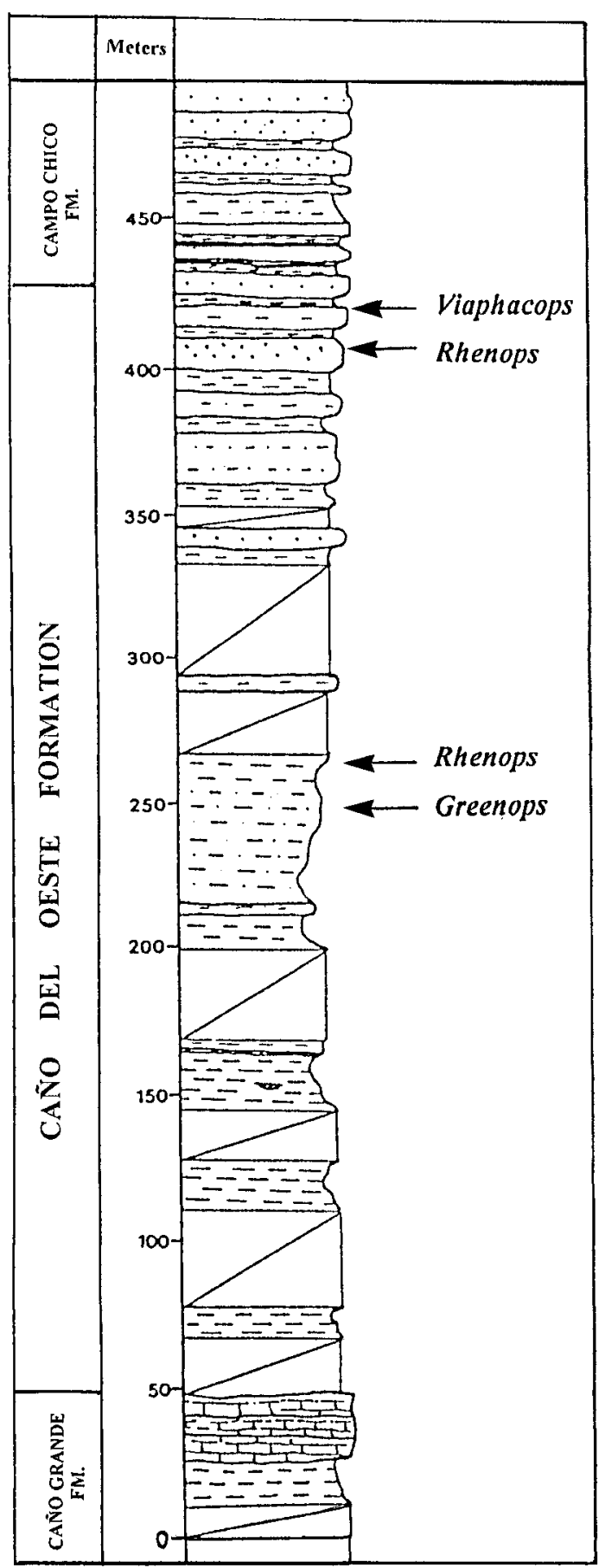

Fig. 2. Geological column for the Caño del Oeste Formation, Caño Colorado Area, Perijá Mountains, Zulia, Venezuela (after Benedetto, 1984), showing the approximate stratigraphic levels of the trilobites described in this study. 

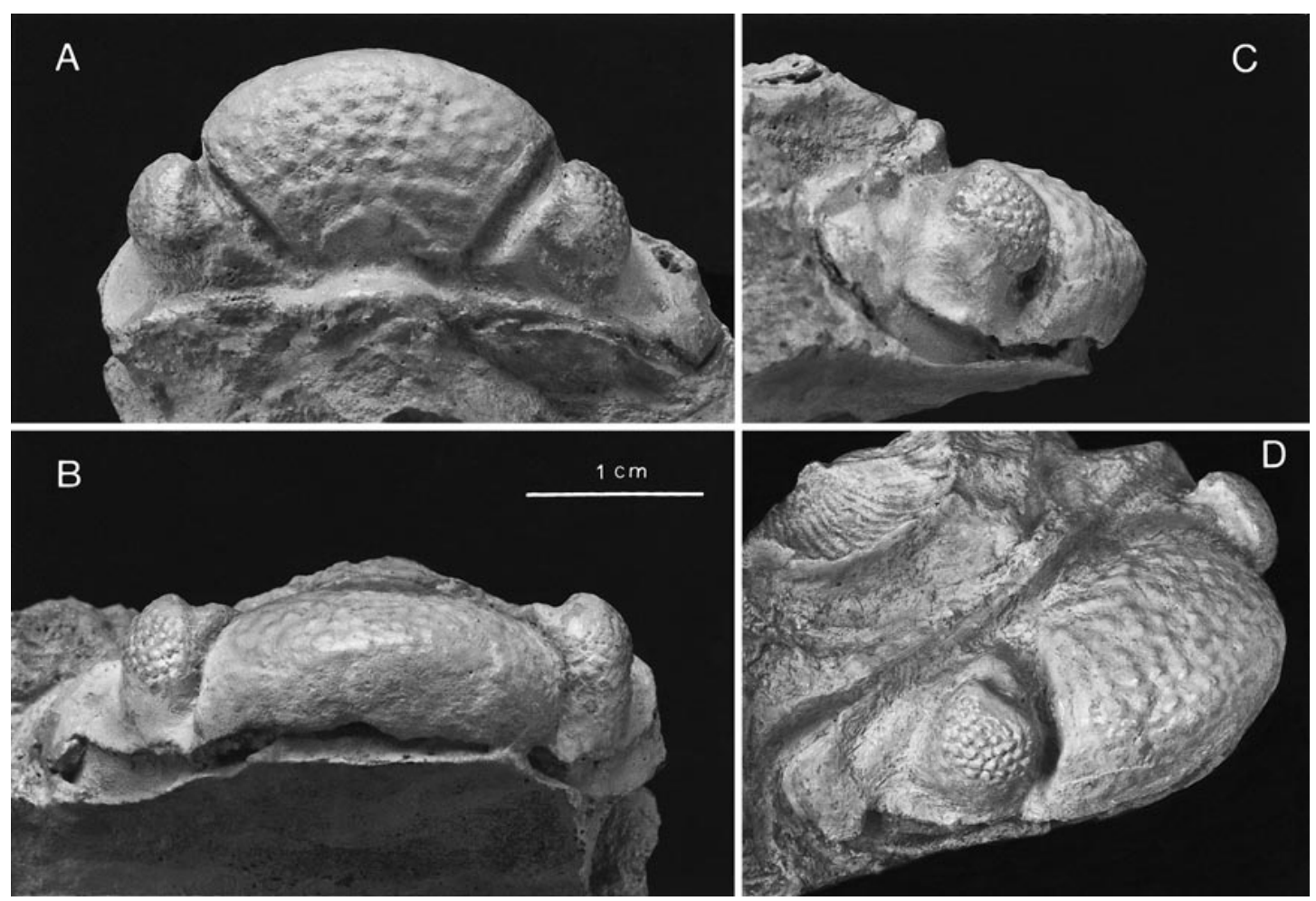

Fig. 3. Viaphacops venezuelensis, n. sp., holotype, MBLUZ P-33, internal mold of cephalon. (A) Dorsal view; (B) frontal view; (C) lateral view; (D) oblique dorsolateral view of right side.

Viaphacops venezuelensis, new species Figure 3, A-D

Diagnosis: Cephalon broader than long, with posterior border slightly concave. Composite glabellar lobe short and broad, rounded anteriorly, flattened dorsally, with moderate inclination anteriorly. Glabellar surface ornamentated with low, rounded tubercles, each one somewhat separated from the others, and gradually diminishing in size anteriorly. Occipital ring without spines or tubercles. Genal angles rounded. Eyes with 13 or 14 dorsoventral files, with 3 or 4 lenses per file. Visual surface convex, raised somewhat above glabellar level.

HolotyPE: MBLUZ P-33, cephalon (represented by an internal mold), from upper level of the Caño del Oeste Formation, Perijá Mountains, NW Venezuela. Cast of holotype AMNH 46578.

EтYMOLOGY: Named after Venezuela, the country of origin.
Age: Middle Devonian (Eifelian/Givetian).

DESCRIPTION: The cephalon is approximately twice as broad as long, with a maximum cephalic width of $34 \mathrm{~mm}$ (adjacent to genal angles), and a maximum length of 16 $\mathrm{mm}$ (sagittally from front of glabella to posterior margin of occipital ring). Dorsally the glabella is moderately inflated, flattened, and inclined forward, and anteriorly its frontal surface is vertical. The length (sag.) of the composite glabellar lobe is $12 \mathrm{~mm}$ (formed by the union of the anterior, third, second, and medial portion of the first glabellar lobes; Eldredge, 1973: 316). The composite glabellar lobe is covered by low, rounded tubercles, each one somewhat separated from the others and diminishing gradually in size toward the anterior region of the glabella. Tubercles are not present on the occipital ring or genae. The maximum anterior glabellar width at the intersection of the axial 
furrows and anterior cephalic margin equal $20 \mathrm{~mm}$. The posterior glabellar width is 10 $\mathrm{mm}$. The axial furrows are straight, broad, deep, and strongly divergent anteriorly. The second and third glabellar furrows are shallow, almost indistinct. A deep, broad transglabellar furrow is apparently formed by confluence of the occipital furrow (S0) and first pair of glabellar furrows (S1). All the paired glabellar lobes are incorporated into the composite glabellar lobe. The distal portion of the first glabellar lobe (L1) forms a pair of lateral preoccipital lobes. The visual surface is supported by an eye socle, elevating the eye somewhat above the level of the glabella. The palpebral lobes are well developed but are not so high as the visual surface. The eyes have 13 or 14 dorsoventral files on the visual surface (the posteriormost files are somewhat indistinct, but there are certainly no more than 14 files). In each file the number of lenses is no more than four lenses per file (in the anteriormost two files there are only two or three lenses). The genae are almost vertical and extend posteriorly behind the occipital ring. The genal angles are rounded. The occipital ring is narrow (long.), without ornamentation or spine, slightly curved anteriorly (sag.), slightly above the glabellar lobe, with a width of $10 \mathrm{~mm}$. The posterior margin of the cephalon and the occipital ring are both raised to form a prominent margin.

The thorax and pygidium are unknown.

\section{MORPHOLOGICAL COMPARISON WITH OTHER VIAPHACOPS SPECIES}

The specimen studied here differs from Viaphacops pipa (Hall and Clarke, 1888; type species of the genus) in the shape of its composite glabellar lobe (less inflated and not protuberant in $V$. venezuelensis), genal angles (rounded in $V$. venezuelensis; short, blunt spines in V. pipa), and eyes (above glabellar level in $V$. venezuelensis; below glabellar level in V. pipa). In both species, however, the eyes are set well forward on the cephalon a considerable distance from the posterior cephalic margin.

Viaphacops nasutus (Stumm, 1954) differs from $V$. venezuelensis in the shape of the cephalon (subtriangular in V. nasutus; more broad than long in $V$. venezuelensis); shape of the composite glabellar lobe (pentagonal in $V$. nasutus, about $2 / 3$ as long as wide, with a produced anterior region; short and broad in $V$. venezuelensis); and genal angles (short, with a nodose genal spine in $V$. nasutus; rounded in $V$. venezuelensis). In both species the eyes are slightly higher than the glabella.

Viaphacops canadensis (Stumm, 1954) differs mainly in the shape of the genal angles (narrow, with sharp genal spine, angled obliquely upward in $V$. canadensis; rounded in $(V$. venezuelensis) and eye size (smaller in $V$. canadensis than in $V$. venezuelensis). Similarities between these two species include the occipital ring, which lacks a spine or node, ornamentation of the glabella, and the shape of the cephalon.

Viaphacops cristatus (Hall, 1861) differs from $V$. venezuelensis in having the glabella more inflated and in possessing an occipital spine and large genal spines.

Viaphacops orurensis (Bonarelli, 1921) from Bolivia differs from $V$. venezuelensis in the shape of the glabella (pentagonal and strongly inflated in $V$. oururensis; moderately inflated and flattened in $V$. venezuelensis), the form of the genal angles (with short spines in $V$. oururensis; rounded in $V$. venezuelensis), and the number of dorsoventral files and lenses per file in the visual surface (17/5-7 in $V$. oururensis; 13 or $14 / 4$ in $V$. venezuelensis). The number of dorsoventral files is somewhat higher in $V$. oururensis than in all other Viaphacops spp. Both species have the occipital ring narrow and raised above the glabella.

Three other species from Bolivia have also been referred to Phacops (Viaphacops) by Pek and Vaněk (1991). All three of these taxa (V. multicinctus, spatiosus, and kozlowski) show some differences from $V$. venezuelensis, especially in the shape of the frontal glabellar lobe and the genal spines. A review of Viaphacops from Bolivia is currently in preparation by Y. Iwasaki and no further comparison with this material will be made here.

\section{REMARKS ON BENEDETTO'S (1979) PHACOPS SP. CF. P. RANA}

Although the phacopine material referred to Phacops sp. cf. rana by Benedetto (1979) 
was unavailable for comparison, from his published description it can be excluded from the genus Viaphacops by the following characters: (a) presence of preoccipital lobe (absent in Viaphacops); (b) strongly rounded glabella covered with dense tubercles almost confluent with each other (less rounded glabella, with fewer and more widely spaced tubercles in Viaphacops); (c) 18 dorsoventral files on the visual surface (only 13-14 in Viaphacops).

It is concluded that Benedetto's (1979) phacopine material does not represent the same taxon we have, and there may be at least two different phacopine taxa represented in this assemblage. Weisbord's (1926) phacopine specimen lacks the cephalon and cannot be compared with our material.

SUPERFAMILY ACASTOIDEA DELO, 1935

FAMILY ACASTIDAE DELO, 1935

SUBFAMILY ASTEROPYGINAE DELO, 1935

Genus Rhenops Richter \& Richter, 1943

Type SPECIES: Cryphaeus anserinus Richter, 1916; Lower Devonian, Eifel (Germany).

Generic Diagnosis: See Struve, 1959: O483.

REMARKS: This genus is known from the Lower Devonian (Emsian) of Europe (Germany, France, and Spain) and Middle Devonian (Eifelian) of Africa (Morocco). The presence of Rhenops in the Devonian of Venezuela was recently noted by Lieberman and Kloc (1997). There are still no records of this genus in North America.

Rhenops odremani, new species Figures 4, A-F; 5 A, B

Rhenops, n. sp., Lieberman and Kloc, 1997: 76, fig. $15,1-8$.

DiAgnosis: Cephalon relatively elongate in outline, ogival, with anterior cephalic border slightly pointed medially; S3 faintly sinusoidal, glabellar lobes not inflated; genal spines long and broad, slightly curved at their extremities, with a ridge on the dorsal surface extending from the cephalic posterior border to the tip. Eyes above glabellar level with maximum of seven lenses per dorsoventral file.

Holotype: MBLUZ P-987, external mold of cephalon lacking the left genal spine, plus parts of first three thoracic segments. Cast of holotype AMNH 46579. Dimensions of the holotype: cephalic length (sag.) approximately $12.6 \mathrm{~mm}$ from occipital furrow to anterior margin of cephalon; width approximately $22.2 \mathrm{~mm}$ across posterior margin of cephalon.

PARATYPES: MBLUZ P-985, internal mold of pygidium; MBLUZ P-986, internal mold of cephalon with part of the right genal spine, plus first three thoracic segments; MBLUZ P-1079, small enrolled specimen with the pygidium preserved (not figured). Casts of paratypes AMNH 46580, 46581, 46582. All material of Rhenops odremani n. sp. is housed in the Museo de Biología, Universidad de Zulia (MBLUZ), Maracaibo, Venezuela, not in the Department of Geology, University of Rio de Janeiro, Brazil, as was stated by Lieberman and Kloc (1997: 77). Catalog numbers for the specimens illustrated in Lieberman and Kloc (1997: fig. 15) are as follows: Nos. 1, $2=$ MBLUZ P-1079; Nos. 3-6 = MBLUZ P-986; Nos. 7, $8=$ MBLUZ P-985.

Etymology: Named for Oscar Odreman, who has made significant contributions to the paleontology of Venezuela.

Provenance And Age: Caño del Oeste Formation, Middle Devonian (Eifelian/Givetian), Perijá Mountains, NW Venezuela.

DESCRIPTION: The cephalon has a relatively elongate outline, tapering anteriorly, and thus resembles a gothic arch (ogival shape), with the anterior cephalic border slightly pointed medially. The cephalic profile is moderately convex. Axial furrows are narrow, well impressed, subparallel to $\mathrm{S} 1$ then becoming divergent anteriorly. Glabellar furrows are weakly impressed and moderately wide. S1 is roughly crescent-shaped and deeper adaxially; S2 is transverse, narrower than S1; S3 is faintly sinusoidal. Lateral glabellar lobes (L1-L3) are flat sagittally. The first pair of lateral glabellar lobes (L1) is somewhat flexed forward, giving the appearance of a transglabellar lobe; L2 is approximately rectangular and smaller than L3, which has a wedge shape. The frontal glabellar lobe is strongly expanded anteriorly and laterally, with its margin smoothly rounded in dorsal view, sloping gently anteriorly and laterally. 

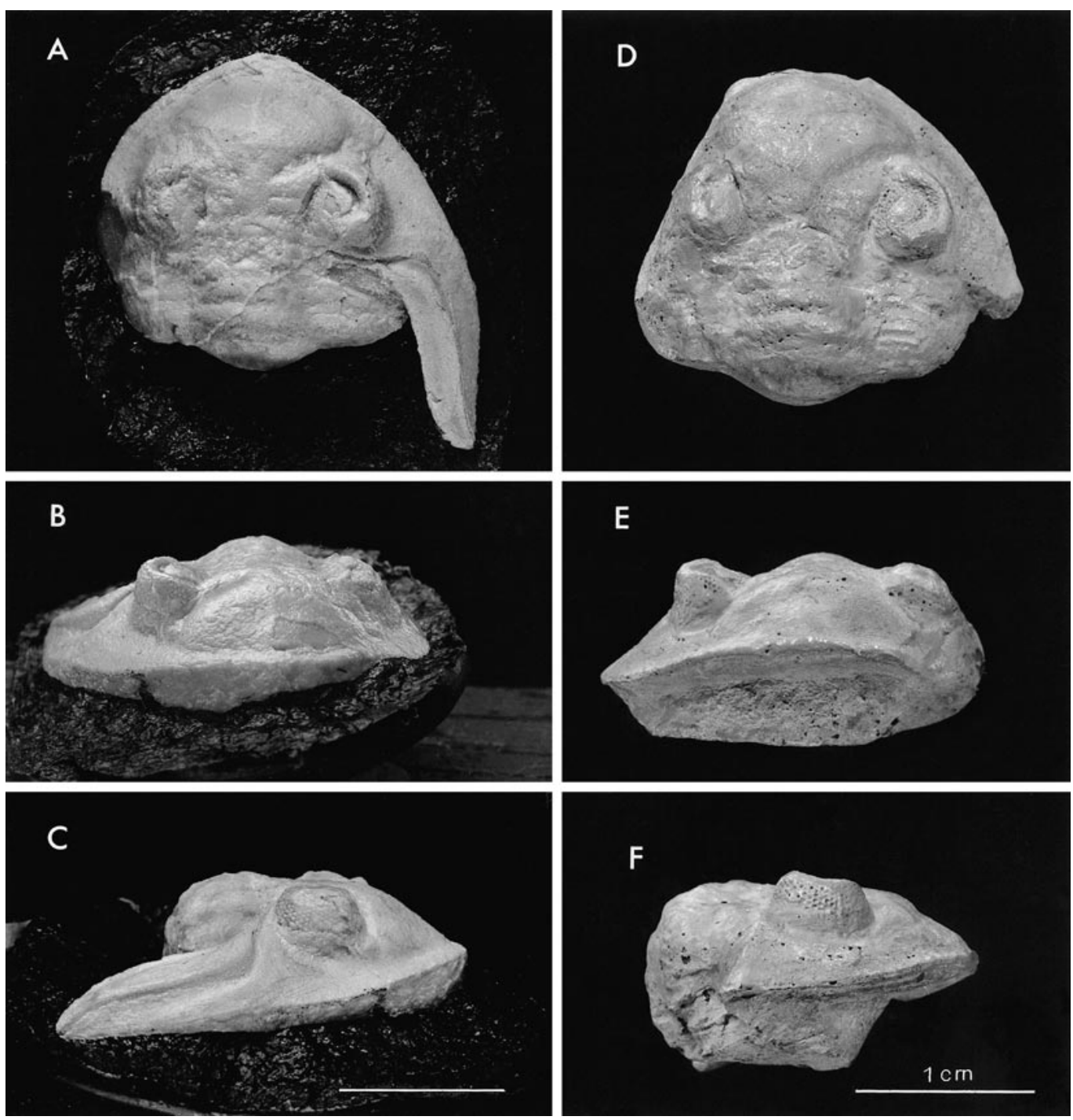

Fig. 4. Rhenops odremani, n. sp. (A-C) Cast made from holotype (an external mold), MBLUZ P987, in (A) dorsal view; (B) frontal view; (C) lateral view; (D-F) Paratype, MBLUZ P-986; internal mold of cephalon in (D) dorsal view; (E) frontal view; (F) lateral view.

The cephalic lateral border furrow is not discernible; the cephalic posterior border furrow is deep and flexed forward medially. The eyes are large and raised above the glabella, occupying about $50 \%$ of glabellar length, and are positioned proximally and posteriorly on the cephalon. Each eye is in contact with the anterolateral corner of L3 anteriorly, and posteriorly is located a short distance from the axial furrow. The posterior edge of the visual surface is situated posteriorly to a transverse line tangent to the anterior edge of the occipital ring. The visual surface has a maximum of seven lenses per dorsoventral file. The palpebral region of the fixigena slopes toward the glabella. Genal spines are relatively long and broad, curved at their extremities, with a ridge on the dorsal surface extending from the cephalic posterior border furrow to the tip. The internal margins of the genal spines are not parallel to the sagittal line, but are deflected posteriorly at an angle 

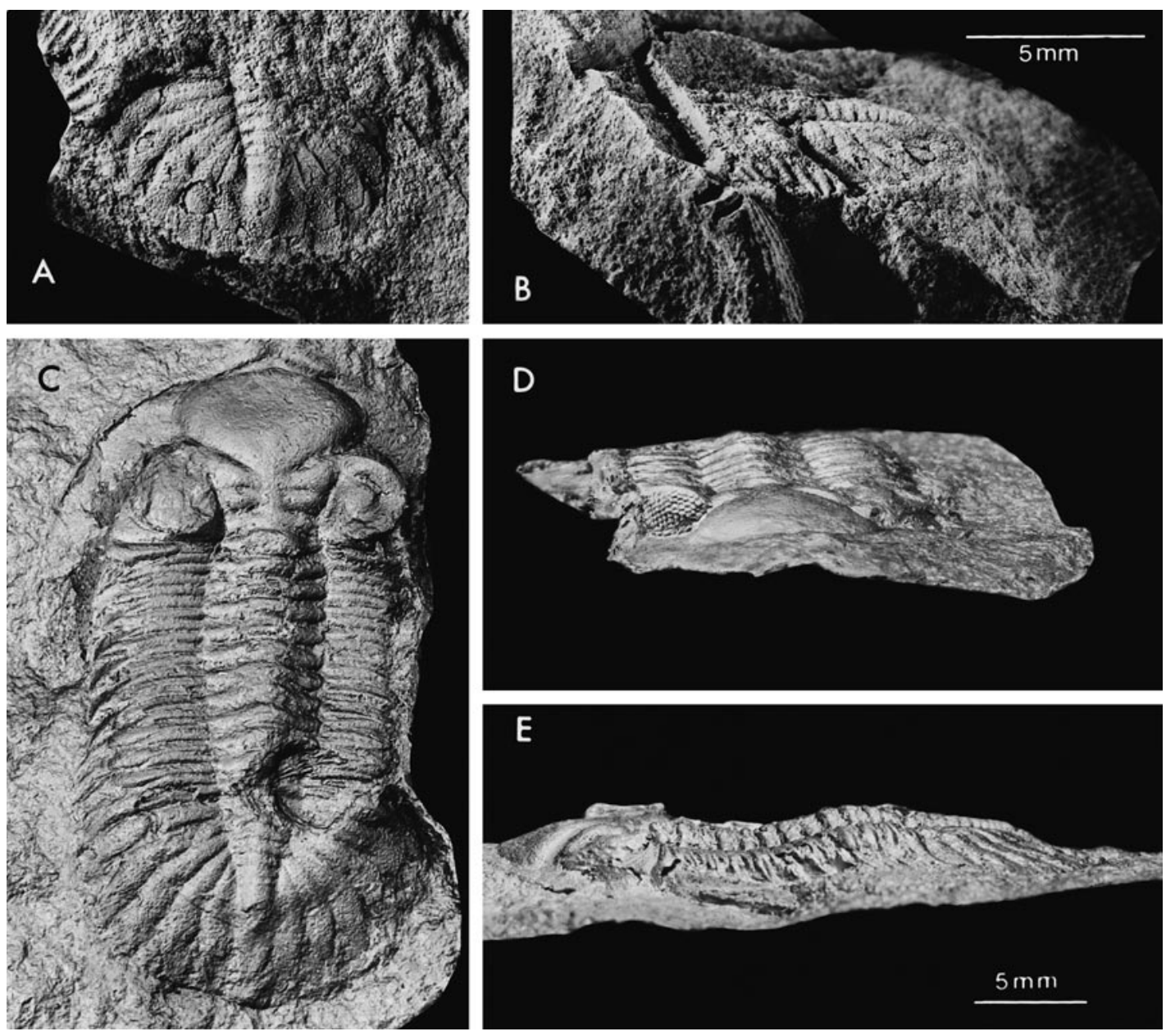

Fig. 5. (A, B) Rhenops odremani, n. sp. Paratype, MBLUZ P-985; internal mold of pygidium. (A) dorsal view; (B) lateral view. (C-E) Greenops perijaensis, n. sp., latex cast of external mold in the holotype, MBLUZ P-1448. (C) Dorsal view; (D) frontal view; (E) lateral view.

of approximately $15^{\circ}$. The length of the genal spine cannot be determined accurately in any of the available specimens; it has approximately the same length as the rest of the cephalon. The occipital ring is not well preserved in the material and its morphology cannot be determined. The preserved surface of the cephalon is rough and has a granular appearance in places. In epoxy casts the surface appears to be tuberculose (fig. 4B), but this is an artifact of the casting medium. We have not found convincing evidence that tubercles are present on the original specimen.

The pygidium is lacking in the holotype of Rhenops odremani, new species, but is pres- ent in two of the paratypes (MBLUZ P-985 and MBLUZ P-1079). The following description is based mainly on MBLUZ P-985 as the pygidium is better preserved than in MBLUZ P-1079. The pygidium is small and subelliptical in outline; in MBLUZ P-985 it has a total length of approximately $5.6 \mathrm{~mm}$ (sag.) and maximum width about $9.6 \mathrm{~mm}$ (its anteriormost region). In lateral view the posteriormost region of the axis slopes to the rear. The axis is slightly raised above the pleural field, and includes at least 10 rings. The first seven rings are easily distinguished, but the remainder become progressively obsolete posteriorly and cannot be accurately 
counted. The anterior margins of the first five rings are slightly arched anteriorly; after the fifth ring they are straight. The axis tapers posteriorly as far as the fifth ring, after which the axial furrows are roughly parallel back to the terminus of the axis. The pleural region consists of five pairs of pleurae of approximately equal width, and with equally elevated anterior and posterior pleural bands; the pleural furrows are deeper than the interpleural furrows. The first three pleurae are gently curved posteriorly, and the last two are curved more abruptly. The fifth pleura is much shorter than the others and it is very close to the pygidial axis. Each pleura terminates with a long, broad, and flat lappet, but its distal tips are not well preserved. The external lateral margin of each lappet is smoothly curved and the inner margin is approximately straight. The terminal lappet is slightly broader than the posterior part of the axis, but its terminal part is missing. No ornamentation is present on the pleurae or pygidial axial rings. The only ornamentation observed in these specimens is fine granulation on the lappets, but other details are difficult to ascertain as both the available pygidia are weathered.

\section{CHARACTERIZATION OF VENEZUELAN RHENOPS BY LIEBERMAN AND KLOC (1997)}

Lieberman and Kloc (1997) included the Venezuelan material described here in their phylogenetic analysis of the subfamily Asteropyginae, which used 39 taxa and 66 characters. Some of their codings for this material are considered questionable here (mostly for preservational reasons), including characters $24,26,40,42,44,57$, and 58 (adult prosopon; length of genal spine; shape of pygidial lappet; lateral margins of pygidial lappets; distal tips of pygidial lappets; number of pygidial axial rings; margin of terminal pygidial lappet). We would also recode character 39 (ornament on medial part of pygidial and thoracic axial rings) from state 1 (tubercles) to 0 (absent). Even after these changes, however, reanalysis using an identical procedure did not alter the phylogenetic position of the Venezuelan material within the genus Rhe- nops, and their basic conclusions were not affected.

\section{COMPARISON WITH OTHER RHENOPS SPECIES}

The rounded anterior margin of the cephalon and the position of the eyes (extending to the lateral border furrow of the cephalon) distinguish Rhenops anserinus (Richter, 1916) from the Venezuelan species. Tubercles are present on the pygidial axial rings in $R$. anserinus but are absent in Rhenops odremani.

Rhenops babini Morzadec, 1983 has a maximum of eight lenses per dorsoventral file on the visual surface, whereas rhenops odremani has a maximum of seven. The shape of the genal spine is also distinct; in $R$. babini the spine is developed medially as a flattened ledge, while in the Venezuelan species there is a ridge along its surface. The fifth pair of pygidial lappets is twice as long as the other lappets in $R$. babini, but it is roughly of the same length as the others in Rhenops odremani.

Rhenops circumapodemus Smeenk, 1983 is distinguished from Rhenops odremani in having a wide ogival cephalon shape; L3 and L2 slightly swollen; a maximum of nine lenses per dorsoventral file on the visual surface; long pygidium with 14 or 15 axial rings; five pairs of sickle-shaped pygidial lappets, with the fifth pair longer and more pointed than the others; terminal pygidial lappet reduced to rounded posterior border.

In Rhenops index Richter and Richter 1943, the terminal pygidial lappet is longer than the other five pairs (its length cannot be accurately determined in $R$. odremani, but it seems not to be elongated), and tubercles are present on the axial rings of the pygidium (absent in $R$. odremani).

Rhenops lethaeae (Kayser, 1889) has a very distinct pygidial morphology, with two small rounded cavities on the first five pygidial axial rings, located abaxially but not in contact with the axial furrows (cavities absent in $R$. odremani); furthermore, the distal tips of the pygidial lappets are developed as blunt triangles, but the shape of the tips of the pygidial lappets cannot be determined in Rhenops odremani. In both Rhenops anseri- 
nus (Richter, 1916) and R. lethaeae (Kayser, 1889) the visual surface is expanded laterally, reaching the lateral border furrow of the cephalon. In Rhenops odremani the visual surface is less expanded laterally and does not reach the lateral border furrow.

Rhenops rodesianus Morzadec, 1981, is readily distinguished from all other members of the genus (including the Venezuelan form) by its genal spines, which are longer than the entire thorax; as in $R$. circumapodemus Smeenk, the fifth pair of pygidial pleural lappets is longer than the others.

It is concluded from the above comparison that the form described here differs from species of Rhenops described from Europe and North Africa (Morocco), and these differences are regarded as sufficient to erect a new species on the basis of a unique character combination.

Inclusion of these Venezuelan fossils in Rhenops, by Lieberman and Kloc (1997), and here is of considerable biogeographic interest, because it represents a significant extension of the genus geographic range.

Genus Greenops Delo, 1935

TyPE SPECIES: Cryphaeus boothi Green, 1837; Middle Devonian of North America (Pennsylvania).

EMENDED Diagnosis: As for Lieberman and Kloc (1997: 77) except for: six or seven lenses in dorsoventral file on visual surface; genal spine developed as moderately long flange extending back to fifth or sixth thoracic segment.

REMARKS: This genus has been rediagnosed and discussed by Lieberman and Kloc (1997), along with the designation of a neotype for Greenops boothi.

Greenops perijaensis, new species Figure 5, C-E

DiAgnosis: Cephalon semicircular in outline, with anterior border pointed; frontal glabellar lobe expended anteriorly and laterally, genal spine flat, smooth, extended to sixth thorax segment; eyes with maximum of seven lenses per dorsoventral file; visual surface in dorsal view lies partly within a sagittal line drawn tangentially to the frontal lobe; pygidium with five pairs of triangular lappets all approximately the same size as their respective pleurae and in contact with each other proximally for at least $30 \%$ of their length; tips of first three, pointed; fourth and fifth, somewhat rounded.

Holotype: MBLUZ P-1448 A and B, part and counterpart of an almost complete specimen with total length of approximately 29 $\mathrm{mm}$, from upper level of the Caño del Oeste Formation, Perijá Mountains, NW Venezuela. Cast of holotype AMNH 46583.

Etymology: Named for Perijá Mountains, of NW Venezuela.

DESCRIPTION: The cephalon is semicircular in outline, moderately convex, a little more than twice as wide as long, with length (sag.) approximately $8.7 \mathrm{~mm}$ and an inferred width (across the posterior border of the cephalon) of $19 \mathrm{~mm}$ (the right side is incomplete). The anterior cephalic border is pointed medially. The axial furrows are moderately wide; they are more divergent anteriorly from $\mathrm{S} 1$. The glabella has three distinct pairs of lateral glabellar furrows. S1 is moderately wide, developed as a smooth convex curve posteriorly, becoming deeper proximally and in contact with the axial furrows. S2 is roughly transverse, with its anterior margin weakly convex, and almost reaching the axial furrows. S3 is widest distally and slightly convex anteriorly. The frontal glabellar lobe is expanded anteriorly and laterally, declines smoothly forward, has a rounded anterior margin, and represents about $70 \%$ of total glabellar length. The glabellar lobes are flattened, their height decreases posteriorly (from L3 to L1), with the medial region flat. L3 is wedge-shaped, lengthening distally; L2 is approximately rectangular, and L1 is narrower than L2. S0 is shallower than S1, moderately wide, convex anteriorly (sag.). The occipital lobe (L0) is longest sagittally, higher medially, slightly above the median area of glabella; becoming lower and narrower distally, without ornamentation. The eyes are raised slightly above the glabella, with a maximum of seven lenses per dorsoventral file on the visual surface. The anterior edge of the visual surface contacts the axial furrow at the anterolateral corner of L3; the posterior edge of the visual surface is located posterior to a transverse line tangent to the anterior edge of LO. In dorsal view the visual surface 
lies partly within a sagittal line drawn tangent to the frontal lobe. The fixigena slopes from the axial furrow to the palpebrum; the librigena is moderately declined toward the lateral cephalic border, whose margin forms a broad continuous arch. The posterior cephalic border furrow is nearly transverse and broadest distally, and the posterior cephalic border widens abaxially. Genal spines are flat and smooth, and extend back to the sixth thoracic segment (their exact length is not very clear on the specimen). No ornamentation is observed on the cephalon.

The thorax contains 11 moderately convex segments, with the axis occupying about one third the width of the thorax (maximum thorax width $17.6 \mathrm{~mm}$; axis width $6.1 \mathrm{~mm}$ ). Axial furrows are shallow but well defined. The axis is somewhat higher than the pleural field. Each axial ring is of uniform length (exsag., sag.) with the medial portion convex anteriorly and higher than the distal extremities, which have an almost straight anterior margin and a convex posterior margin. The articulation furrows are moderately wide and deep. The proximal part of the pleura is transverse, approximately horizontal, whereas the distal part is strongly flexed downward. Pleural furrows are moderately deep, wide, and almost straight.

The pygidium is broad, semicircular in outline, approximately $9.4 \mathrm{~mm}$ long (sag.) and $16.3 \mathrm{~mm}$ wide (maximum width anteriorly). The axis is raised slightly above the pleural fields, and is well defined by narrow and shallow axial furrows. Only the first seven axial rings are distinct, plus the anterior part of the eighth. Axial rings are delimited by shallow and moderately wide ring furrows. The first five axial rings are gently flexed anteriorly at the midline and are of nearly equal length throughout; the more posterior rings are almost straight. There are five pairs of pleurae; the first three are gently curved backward and the last two are more abruptly flexed; pleurae become slightly wider distally. Interpleural furrows are obsolete; the pleural furrows are shallow and relatively wide. The first three pleural furrows are more conspicuous than the posterior two. The anterior and posterior bands of the pleural segments lie at the same level. The border furrow is well defined. There are five pairs of triangular lappets, all approximately the same size as their respective pleurae. The distal tips of the first three lappets are pointed, but the fourth and fifth are somewhat rounded. The lappets make contact with each other proximally, for at least $30 \%$ of their length, but are separated distally. The lateral margins of the lappets are curved posteriorly, whereas their inner margins seem to be straight. The lappets are covered by small, dense granules. The terminal lappet is approximately equal in length (sag.) to the fifth lappet, although its end is not very clear in the specimen.

\section{DISCUSSION}

Liebermann and Kloc (1997) diagnosed Greenops on the basis of 18 characters: 6, 8, $21,26,28,29,31,33,34,35,42,45,47,49$, $50,51,57$, and 66 (see their data matrix and character states in tables 1 and 2), of which 12 are discernible in the Venezuelan material $(21,28,29,31,33,34,42,45,47,49,50$, and 51); the remaining characters cannot be determined for preservational reasons. The new taxon differs from their generic diagnosis in two aspects; there are seven lenses in the dorsoventral file in the visual surface instead of six; and the genal spine extends to the sixth thoracic segment instead of the fifth (characters 6 and 26 of Lieberman and Kloc, 1997). We have opted here to include the Venezuelan form within an emended concept of Greenops (see diagnosis), rather than to erect a new genus for our unique specimen.

Greenops perijaensis differs from G. boothi (Green, 1837; the type species of the genus) in having $\mathrm{S} 1$ less deep and not as crescentshaped as in G. boothi; L0 without medial tubercle (present in G. boothi); shape of pleural lappets (separated in G. boothi, joined proximally for at least $30 \%$ of their length in the new species; terminal lappet of equal length to fifth lappet in G. perijaensis, (shorter in G. boothi); lappets covered by dense granulation in Greenops perijaensis (no lappet ornamentation in G. boothi).

Greenops perijaensis is readily distinguished from Greenops barberi Lieberman and Kloc, 1997 by the absence of ornamentation on the glabella, genal field, and genal spines (fine tubercles are present in G. bar- 
beri); the shape of pygidial lappets (very pointed in $G$. barberi; in $G$. perijaensis the first three are pointed, and the last two are rounded); and relative length (sag.) of the terminal lappet (smaller than the fifth lappet in G. barberi; equal size in G. perijaensis).

Greenops grabaui Lieberman and Kloc, 1997 is distinguished from Greenops perijaensis by its ornamentation (fine tubercles in G. grabaui, mainly on the glabella), presence of circular fenestrae on thoracic axial rings (absent in G. perijaensis); presence of one transverse row of circular fenestrae on the anterior band of thoracic pleural segment (absent in G. perijaensis); and shape of the pygidial lappets (distal tips developed as blunt triangles in G. grabaui; in G. perijaensis the first three are pointed, the fourth and fifth are somewhat rounded.

Greenops chilmanae Stumm, 1965 differs from G. perijaensis in having a much narrower glabella posteriorly, and has tubercles covering the glabella; tubercles are also present on the palpebral lobes, the axial part of the occipital ring, and the genal spines.

Greenops widderensis Lieberman and Kloc, 1997 differs from G. perijaensis in having the anterior cephalic border rounded; tubercles on glabella and L3; visual surface in dorsal view not located within a sagittal line drawn tangent to the frontal lobe; a single row of circular fenestrae on the anterior band of thoracic pleural segments, and all pygidial lappets pointed.

\section{BIOGEOGRAPHIC CONSIDERATIONS}

The trilobite assemblage from the Middle Devonian of Venezuela (Caño del Oeste Formation) includes two representatives of the family Phacopinae. One of these represents a new species of Viaphacops (described here), and the other was referred by Benedetto (1979) to Phacops. The assemblage also includes two new species of the acastid subfamily Asteropyginae, one referable to the genus Rhenops and the other to Greenops. Some commentary seems worthwhile regarding the biogeographic significance of these occurrences. The Venezuelan phacopine material described previously by Weisbord (1926) and Benedetto (1979) is too poorly known to be of biogeographic value.
(1) Viaphacops. Localities from which Viaphacops is recorded are geographically widespread, including Kazakhstan, North America, and South America. These occurrences also fall within several different biogeographic areas. Maximova (1972) included Kazakhstan within a large "Pacific paleogeographic region," but that concept is rather generalized. According to Meyerhoff et al. (1996), Kazakhstan falls inside the BalkhashMongolia-Okhotsk region of the Old World realm. The North American and Venezuelan occurrences of Viaphacops lie within the Eastern Americas realm (sensu Boucot, 1988), and its Bolivian occurrence is within the Malvinokaffric realm (sensu Eldredge and Ormiston, 1979). Viaphacops is thus a relatively cosmopolitan genus and it occurs in both warm- and cold-water assemblages, suggesting it was eurytopic.

In Bolivia Viaphacops is known from the Lower Devonian (Pragian, Gamoneda Formation, its earliest known occurrence; also Emsian, Belén and Icla Formations). In North America its geological range extends from the Lower to Middle Devonian (Emsian-Eifelian). In Kazakhstan Viaphacops is also known from the Lower and Middle Devonian, although in this area its stratigraphic range extends farther, into the Givetian (its youngest known occurrence). The distribution of Viaphacops does not therefore characterize any particular biogeographic province, and its distribution pattern is relatively uninformative. Although the range of Viaphacops extended into the southerly coldwater Malvinokaffric realm, no characteristically Malvinokaffric trilobites have been found in the Venezuelan assemblage (Eldredge and Ormiston, 1979).

(2) Rhenops. Until its discovery in Venezuela, the genus Rhenops was known only from within the Rhenish-Bohemian region of the Old World (Boucot, 1988), with occurrences in Europe (upper Emsian of northern Spain, the Armorican Massif, and Germany) and Africa (Eifelian of Morocco). The presence of Rhenops in Venezuela (first noted by Lieberman and Kloc, 1997) extends this range to encompass part of the Eastern Americas realm much farther westward than previously supposed, although its distribution is disjunct. The Middle Devonian paleo- 
position of the Eastern Andean Terrane is uncertain (it may represent an exotic block from Caledonian and Hercynian chains of North America or Europe; Restrepo and Toussaint, 1998). Given the progressively younger age of Rhenops occurrences from east to west, it is tempting to suggest a progressive westward migration of the genus from a center of endemism in Europe, but the fossil record of the genus is too fragmentary to formulate a more rigorous biogeographic hypothesis.

(3) Greenops. Traditionally, Greenops was recognized in Emsian-Eifelian assemblages of Europe and Africa (Arbizu, 1979; Gandl, 1972; Morzadec, 1983; Smeenk, 1983), but in North America it is known only from the Givetian (Hamilton Group: Delo, 1935, 1940; Lieberman and Kloc, 1997; Stumm, 1953, 1965, 1967). These records were spread across two different biogeographic realms: the Old World realm (Rhenish-Bohemian Region, including northern Africa; Boucot, 1988) and the Eastern Americas realm. In their revision of Greenops, Lieberman and Kloc (1997), redefined the genus to include only North American species, and all the Old World taxa formerly assigned to Greenops were excluded from that genus. The Venezuelan occurrence of Greenops represents a southerly extension of its distribution within the Eastern Americas realm, and reinforces the faunal similarities noted by Benedetto (1984) and Boucot (1988) between the Devonian brachiopods of Venezuela and those of eastern North America; and by Eldredge and Ormiston (1979) within the trilobites.

\section{ACKNOWLEDGMENTS}

The authors thank Ascanio Rincón and Reina Rosales for assistance with field collections. This study was undertaken in the Department of Invertebrate Paleontology at the American Museum of Natural History, and we are especially grateful for the support and encouragement provided by Neil Landman and Niles Eldredge. M.G.P.C. thanks John Maisey (AMNH) for discussions about paleogeography and for reviewing the manuscript. Inez Horovitz and Jesus Alvarado kindly helped with the Spanish abstract. Su- san Klofak assisted with preparation and casting of specimens, and the illustrations were prepared by Chester Tarka and Lorraine Meeker. We thank the anonymous reviewers for their very helpful comments and suggestions.

\section{REFERENCES}

Arbizu, M.

1979. Asteropyginae (trilobite) du Dévonien des Montagnes Cantabriques (Espagne). Bull. Soc. Geol. Mineral. Bretagne, sér. C. 9(2): 59-102.

Barret, S. F., and P. E. Isaacson

1988. Devonian paleogeography of South America. In N. J. McMillan, A. F. Embry, and D. J. Glass (eds.), Devonian of the World. Can. Soc. Pet. Geol. Mem. 14(1): 655-667.

Benedetto, J. L.

1979. La fauna de la Formatión Caño del Oeste (Devónico) en la región de Caño Colorado, Sierra de Perijá, Venezuela. P. I: Mollusca y Trilobita. Bol. Geol. (Caracas) 13(25): 81-111.

1984. Les brachiopodes Dévoniens de la Sierra de Perijá (Venezuela). Systematique et implications paléogeographiques, V.1. Brest: Coll. Biostrat. du Paleoz. Univ. Bretagne Occidentale.

Berry, C. M., J. E. Casas, and J. M. Moody

1993. Diverse Devonian plant assemblages from Venezuela. Doc. Lab. Géol. Lyon, 125: 29-42, 4 figs., 1 table.

Boucot, A. J.

1988. Devonian biogeography: an update. In N. J. McMillan, A. F. Embry, and D. J. Glass (eds.), Devonian of the World. Can. Soc. Pet. Geol. Mem. 14(3): 211227.

Delo, D. M.

1935. A revision of the phacopid trilobites. J. Paleontol. 9(5): 402-420.

1940. Phacopid trilobites of North America. Geol. Soc. Am. Spec. Pap. 29: 135 pp.

Eldredge, N.

1972. Systematics and evolution of Phacops rana (Green, 1832) and Phacops iowensis Delo, 1935 (Trilobita) from the Middle Devonian of North America. Bull. Am. Mus. Nat. Hist. 147: 45-114.

1973. Systematics of Lower and Lower Middle Devonian species of the trilobite Phacops Emmrich in North America. Ibid. 151: 289-337.

Eldredge, N., and A. R. Ormiston

1979. Biogeography of Silurian and Devoni- 
an trilobites of the Malvinokaffric Realm. In J. Gray and A. J. Boucot (eds.), Historical biogeography, plate tectonics, and the changing environment: 147-167. Corvallis: Oregon State Unvi. Press.

Gandl, J.

1972. Die Acastavinae und Asteropyginae (Trilobita) Keltiberiens (NE-Spanien). Abh. Senckenb. Natforsch. Ges. 530: $1-184$.

Green, J.

1837. Description of several new trilobites. Am. J. Sci. (1)32: 343-349.

Hall, J., and J. M. Clarke

1888. Descriptions of the trilobites and other Crustacea of the Oriskany, upper Helderberg, Hamilton, Portage, Chemung, and Catskill Groups. Natural History of New York. N.Y. Geol. Surv., Paleontol. V.7.

Hea, J. P., and A. B. Whitman

1960. Estratigrafía y petrología de los sedimentos pre-cretácicos de la parte nortecentral de la Sierra de Perijá, Estad Zulia, Venezuela. Mem. Tercer Congr. Geol. Venez. 1: 351-376. Caracas: Editorial Sucre.

Liddle, R. A., G. D. Harris, and J. W. Wells

1943. The Rio Cachiri section in the Sierra de Perija, Venezuela. Bull. Am. Paleontol. 27: 269-375, Ithaca.

Lieberman, B. S., and G. J. Kloc

1997. Evolutionary and biogeographic patterns in the Asteropyginae (Trilobita, Devonian) Delo, 1935. Bull. Am. Mus. Nat. Hist. 232: 1-127.

Linsley, D. M.

1994. Devonian paleontology of New York. Paleontol. Res. Inst. Spec. Publ. 21.

Maximova, Z. A.

1972. New Devonian trilobites of the Phacopoidea. Paleontol. J. 1: 78-83.

Meyerhoff, A. A., A. J. Boucot, D. M. Hull, and J. M. Dickins

1996. Phanerezoic faunal and floral realms of the Earth: the intercalary relations of the Malvinokaffric and Gondwana faunal realms with Tethyan faunal realm.

Morzadec, P. Geol. Soc. Am. Mem. 189: 1-69.

1983. Trilobites du Devonien (Emsien - Famennien) de la rade de Brest (Massif Armoricain). Palaeontographica (A) 181: 103-184.

Morzadec, P., F. Paris, and P. Racheboueuf.

1981. La Tranchée de la Lezais Emsien Supérieur du Massif Armoricain (sédi- mentologie, paléontologie, stratigraphie). Les Trilobites. Mém. Soc. Géol. Minéral. Bretagne 24(313): 279-291.

Pek, I., and J. Vanĕk

1991. On some Silurian and Devonian trilobites of Bolivia. Acta Universitatis Palackiana Olomucensis, Fac. Rer. Nat. Geogr.-Geol. XXX, 103: 75-104.

Pillet, J.

1958. Contribution à l'étude de quelques Asteropyginae. Bull. Soc. Géol. France (6)8: 3-20.

Ramsköld, L., and L. Werdelin

1991. The phylogeny and evolution of some phacopid trilobites. Cladistics 7: 2974.

Restrepo, J. J., and J. F. Toussaint

1998. Terranes and continental accretion in the Colombian Andes. Episodes 11(3): 189-193.

Smeenk, Z.

1983. Devonian trilobites of the southern Cantabrian Mountains (northern Spain) with a systematic description of the Asteropyginae. Leidse Geol. Meded. 52: $383-511$.

Struve, W.

1959. Asteropyginae. In R. C. Moore (ed.), Treatise on invertebrate paleontology, part O, Arthropoda 1: 447-483. Lawrence: Univ. Kansas Press.

Stumm, E. C.

1953. Trilobites of the Devonian. Contrib. Mus. Paleontol. Univ. Michigan, 10(6): 101-157.

1954. Lower Middle Devonian phacopid trilobites from Michigan, southwestern Ontario, and the Ohio Valley. Ibid. 11(11): 201-221.

1965. Two new species of trilobites from the Middle Devonian Silica Shale of North-Western Ohio. Ibid. 19(13): 163166.

1967. Devonian trilobites from north-western Ohio, northern Michigan, and western New York. Ibid. 21(6): 109-122.

Sutton, F. A.

1946. Geology of Maracaibo Basin, Venezuela. Bull. Am. Assoc. Pet. Geol. 30(10): 1621-1741.

Weisbord, N. E.

1926. Venezuelan Devonian fossils. Bull. Am. Paleontol. 11(46): 223-272.

Yaekel, S. W.

1924. Notas provisionales sobre la zona de El Tigre, Estado Zulia, Distrito Mara. Maracaibo: Venez. Atl. Refining Co. 
Recent issues of the Novitates may be purchased from the Museum. Lists of back issues of the Novitates and Bulletin published during the last five years are available at World Wide Web site http://nimidi.amnh.org. Or address mail orders to: American Museum of Natural History Library, Central Park West at 79th St., New York, NY 10024. TEL: (212) 769-5545. FAX: (212) 7695009. E-MAIL: scipubs@amnh.org

(2) This paper meets the requirements of ANSI/NISO Z39.48-1992 (Permanence of Paper). 